\title{
Changes in the Bid-Ask Components around Earnings Announcements \\ Evidence from the Copenhagen Stock Exchange
}

Voetmann, Torben

Document Version

Final published version

Publication date:

2000

License

CC BY-NC-ND

Citation for published version (APA):

Voetmann, T. (2000). Changes in the Bid-Ask Components around Earnings Announcements: Evidence from the Copenhagen Stock Exchange. Institut for Finansiering, Copenhagen Business School. Working Papers /

Department of Finance. Copenhagen Business School No. 2000-6

Link to publication in CBS Research Portal

\section{General rights}

Copyright and moral rights for the publications made accessible in the public portal are retained by the authors and/or other copyright owners and it is a condition of accessing publications that users recognise and abide by the legal requirements associated with these rights.

\section{Take down policy}

If you believe that this document breaches copyright please contact us (research.lib@cbs.dk) providing details, and we will remove access to the work immediately and investigate your claim. 


\section{WP 2000-6}

Change in the Bid-Ask Components Around Earnings Announcements:

Evidence from the Copenhagen Stock Exchange

af

Torben Voetmann

INSTITUT FOR FINANSIERING, Handelshøjskolen i København

Solbjerg Plads 3, 2000 Frederiksberg C

tlf.: 38153615 fax: 38153600

DEPARTMENT OF FINANCE, Copenhagen Business School

Solbjerg Plads 3, DK - 2000 Frederiksberg C, Denmark

Phone (+45)38153615, Fax (+45)38153600

www.cbs.dk/departments/finance

ISBN 87-90705-40-8

ISSN 0903-0352 


\title{
Changes in The Bid-Ask Components Around Earnings Announcements: Evidence from the Copenhagen Stock Exchange
}

\author{
by \\ Torben Voetmann ${ }^{1}$ \\ Finance Department, the Copenhagen Business School
}

\begin{abstract}
:
This paper investigates the relative magnitude of the components in the bid-ask spread around earnings announcements using the method in Stoll (1989). The results show that earnings surprises convey relevant pricing information and that significant information asymmetry exists between the market makers and the informed traders. Around negative earnings announcements the adverse-selection component and the trading volume increase while the inventory-holding and order-processing components decrease. This leads to a decrease in the realized spread. The magnitude of the change in the realized spread appears to be important but the change in the quoted bid-ask spread is negligible. The overall result implies that the informed traders' ability to assess firms' performance only affect the bidask spread around the time of the earnings announcements.
\end{abstract}

Keywords: Bid-Ask Spread; Earnings Surprises; Asymmetric Information JEL classification: G14,

\footnotetext{
1. Finance Department, the Copenhagen Business School and The Wharton School of Business at the University of Pennsylvania. Correspondence: The Wharton School of Business, The Finance Department. 3620 Locust Walk, Suite 2300. Philadelphia, PA 19104-6367. Phone +215.898-7622, Fax: +215.8986200. E-mail: voetmann@wharton.upenn.edu. The usual disclaimer applies.
} 


\section{Introduction}

This paper investigates the components of the bid-ask spread and analyzes the changes in the spread around earnings announcements. The capital market reaction to earnings announcements depends on whether the earnings news contains a positive surprise or a negative surprise. Earnings announcements are shown to convey relevant pricing information that makes it possible to investigate informed investors' advantage in their trading mechanisms. Several studies attempt to explain the impact the quoted bid-ask spread has on asset returns. ${ }^{2}$ Recently, bid-ask spread models examine the behavior of market makers around corporate announcements, such as earnings announcements. For example, Krinsky and Lee (1996) examine announcement effects with the existence of asymmetric information about expected earnings. They find significant and increasing adverse-selection costs around earnings announcements. Similar to Krinsky and Lee (1996), this study shows the development in adverse-selection costs, inventory-holding costs, and order-processing costs using quoted prices and transaction prices from firms that are listed on the Copenhagen Stock Exchange. The three components of the quoted bid-ask spread may be sufficient to cover the market makers' expected compensation for making transactions. However, the market makers' realized compensation for providing the liquidity service is the effective bid-ask spread. ${ }^{3}$ It is therefore important to recognize the economic magnitude of the spread.

If market makers recover costs through the bid-ask spread, it is reasonable to assume that information asymmetry will widen the spread around earnings announcements. Krinsky and Lee (1996) propose two hypotheses, the first argues for an increase in the adverseselection costs prior to earnings announcement because market makers face a greater probability of trading with an informed trader that may possess superior information about expected earnings. The second hypothesis is that the adverse-selection costs increase after earnings announcements because informed traders assess a firm's performance on the basis

\footnotetext{
2 See Roll (1984), Glosten (1987), Glosten and Harris (1988), Copeland and Galai (1988), Stoll (1989), George, Kaul and Nimalendran (1991), Affleck-Graves, Hedge, and Miller (1994), and Krinsky and Lee (1996).

${ }^{3}$ The difference between a dealer's ask and bid prices is the quoted bid-ask spread and the realized or effective bid-ask spread is the average difference between traded ask and bid prices. The quoted spread is almost always less than the realized spread and in the United State it is about half the quoted spread. See Stoll (1989).
} 
of the announcements and superior information. The investigation of the adverse-selection component, using information asymmetric models, suggests that greater information asymmetry between traders and market makers induce a wider bid-ask bounce. Informed market participants incorporate superior information about expected earnings in the pricing process, which forces the market maker to increase the spread as temporary protection against information asymmetry. This study shows that the sum of the three bid-ask components do not change significantly from the pre-event period to the event period. The adverseselection costs change from 52 percent in the pre-event to 72 percent in the event period. This indicates that market makers informational uncertainty about informed traders is increasing. The inventory-holding and order-processing costs decrease over the same periods. Therefore, the quoted bid-ask spread does not change significantly around earnings announcements. The results show that the components in the bid-ask spread vary and they are dependent on sample-specific patterns. Further studies of the bid-ask spread are relevant because of the information asymmetry around earnings announcements.

The results show more informational uncertainty with negative earnings surprises than with positive earnings surprises. A possible explanation of the different market responses to positive and negative earnings surprises may be that firms announcing below than expected earnings creates uncertainty among market participants. Similar to Krinsky and Lee (1996), the results support the hypothesis that adverse-selection costs of the bid-ask spread increases, which implies that the increase occurs because of a higher probability that a market maker is trading with an informed trader with superior information. The economic magnitude of changes in the adverse-selection component for earnings announcements is comparable to the change in inventory-holding and order-processing components, i.e. the quoted spread does not change significantly despite the increase in information asymmetry around earnings announcements. The overall results may be interpreted as evidence of a state of temporarily increased information asymmetry.

The structure of the paper is as follows: section II reviews existing models that explains the bid-ask spread, starting with Roll (1984), and it discusses the transaction pricing proc- 
ess of the expected development in the bid-ask spread around earnings announcements; section III describes the data set of earnings announcements and the empirical methodology, which is similar to the methodology proposed by Stoll (1989) and George et al. (1991); section IV presents the empirical results of estimating the information content in the bid-ask spread and the explanation of the development in the spread; and section V provides concluding remarks.

\section{Explanations of the Bid-Ask Spread}

Ho and Stoll $(1981,1983)$ provide the first real attempt at modeling the components of the bid-ask spread while earlier studies by Demsetz (1968) and Tinic (1972) describe the market makers' ability to provide market participants liquidity service. Ho and Stoll $(1981,1983)$ modeled the behavior of market makers as a result of trading under uncertainty and that the market makers' compensation in part comes from the bid-ask spread because trading moves holding positions away from a preferred inventory level. This inventory-holding cost is the part of the bid-ask spread that reflects the return to market makers for accumulating undesired inventory, i.e. it represents costs to specialists for sustaining a portfolio of stocks that is not fully diversified. ${ }^{4}$ Another component is the order-processing cost that represents the market makers' costs for providing liquidity and processing services for buy and sell orders, i.e. order-processing costs are the market makers' fee for matching buying and selling orders and the insurance for completing transactions. Copeland and Galai (1983) and Glosten and Milgrom (1985) demonstrate that market makers' compensation for the risk of completing transactions with traders that possess superior information are in the form of a higher bid-ask spread. This adverse-selection cost induces a positive bid-ask spread whenever the risk of trading with informed traders is high, i.e. when a market maker believes to be trading with an informed trader the quoted bid and ask prices will decrease (increase) whether the informed trader last bought or sold shares. The

\footnotetext{
${ }^{4}$ The market makers uses the quoted bid-ask spread to adjust inventory holdings, i.e. raising (lowing) the bid and ask prices when inventory becomes low (high).
} 
next section describes models that are developed to explain the different components of the bid-ask spread. ${ }^{5}$

\section{A. Theoretical Models}

Roll (1984) proposes a simple model that account for the impact the bid-ask spread has on asset returns. Roll shows that the covariance of transaction returns is an estimation of the effective spread, i.e. the realized spread in an efficient market, in which the observed market prices depend on a security's fundamental value and the difference between bid and ask prices (Stoll, 1989). The transaction price $P_{t}$ is equal to a fixed fundamental value $P_{t}^{v}$ plus half the spread $1 / 2 S \cdot I_{t}$, where $I_{t}$ is -1 for bid prices and +1 for ask prices. Roll assumes that $I_{t}$ occurs with equal probabilities whether or not a trade is initiated by buyer or seller. Using this simple model, the effective spread is best described by $2 \cdot \sqrt{-\operatorname{cov}} \cdot{ }^{6}$ But, the problem with Roll's description of the spread is that only the order-processing component is included when considering the fundamental value. In addition, it is assumed that the expected return is constant through time and adverse-selection cost does not exist. However, decomposing the bid-ask spread into several factors makes it difficult to explain the behavior of the spread while maintaining an assumption of constant expected returns.

Glosten (1985) provides an asymmetric-information model that only explains the adverse selection cost of the bid-ask spread. Glosten shows that under risk-neutrality the commoninformation price is given by $P=E\left[P^{v} \mid \Omega\right]$ where $\Omega$ is the publicly available information set and the adverse-selection $\left(A_{a}+A_{b}\right)$, inventory-holding and order-processing $\left(C_{a}+C_{b}\right)$ components are decomposed in the bid and the ask price. The spread is the sum of $A_{a}+A_{b}+C_{a}+C_{b}$. Assuming that all traders have the same information set, Glosten uses the

\footnotetext{
${ }^{5}$ Studies on inventory-holding costs and order-processing costs are Demsetz (1968), Stoll (1978), Amihud and Mendelson (1980), and Ho and Stoll $(1981,1983)$. Studies on adverse-selection costs are Copeland and Galai (1983), Glosten (1985), Glosten and Milgrom (1983), Easley and O'Hara (1987), and George, Kaul, and Nimalendran (1991).

${ }^{6}$ This simple measure of the spread is based on two assumptions: 1) the expected return for any given security is constant through time and 2) adverse-selection costs do not exist. George et al. (1991) argue
} 
following expectation operator for possible bid and ask prices; $a(x)=E\left[P_{v} \mid \Omega \cup\{\right.$ investor buys at $x\}]$ and $b(y)=E\left[P_{v} \mid \Omega \cup\{\right.$ investor buys at $\left.y\}\right]$, respectively. Assuming that the market makers determine bid and ask prices so that expected costs are covered in the spread, the quoted bid and ask prices are:

$$
\begin{aligned}
& P_{a}=a\left(P_{a}\right)+C_{a}=P+\left(a\left(P_{a}\right)-P\right)+C_{a}=P+A_{a}+C_{a} \\
& P_{b}=a\left(P_{b}\right)+C_{b}=P+\left(P-b\left(P_{b}\right)\right)+C_{b}=P+A_{b}+C_{b}
\end{aligned}
$$

A major implication of the expected bid and ask prices is that only a portion of the total spread covers the basic costs. In addition, the impact from the quoted bid and ask prices on the transaction prices is a high correlation between the common information price $P_{n}$ after the $n$th transaction and whether a trade $Q_{n}$ is initiated by the buyer or seller, which takes the value -1 and +1 , respectively. The next transaction price is $E\left[P_{n}\right]=P_{n}+Q_{n}$. Glosten (1985) shows that $P_{n}$ and $Q_{n}$ must be correlated due to the existence of adverse-selection costs. Similar to Roll (1984), the change in the transaction prices displays reversals due to the inventory holding and order processing costs but the adverse-selection cost component tends to be permanent. Therefore, it is only inventory-holding and order-processing costs that cause negative serial correlation in returns, which leads Glosten to argue that Rolls measure of the spread understates the realized spread.

George, Kaul and Nimalendran (1991) develop a model that allows for time-varying returns and provides unbiased estimates of the spread and its components. They argue that positive autocorrelation in the expected time varying returns creates an estimation bias. Stoll (1989) argues for unbiased estimates of the probability of a price reversal and price continuation, however, the parameters may be biased because they are nonlinear transformations of prices (Affleck-Graves et al., 1994). To eliminate estimation bias George et al. (1991) propose an alternative model that provides unbiased estimators. However, the model requires zero inventory-holding cost. Using an OLS-regression, it is possible to es-

that the expected time varying returns are positive autocorrelated and therefore the estimators are bias of both the spread and its components. 
timate the adverse-selection and order-processing cost of the spread under the assumption that the spread is independent of trade size and that there exists equal ex-ante probabilities for trading at the bid and the ask price. The estimation allows for the "true" expected return of a security to vary through time. This affects the estimators of the level of the spread and its components. Affleck-Graves, Hedge and Miller (1994) use a version of George et al.'s (1991) model to test for differences between the components on the New York Stock Exchange (NYSE) and the National Association of Security Dealers Automated Quotations $(N A S D A Q)$ /National Market System (NMS) Stocks. The advantage of this approach is that it allows for a separation of the impact from the different systems.

$$
S_{i}=\alpha_{0}+\alpha_{1} \cdot S_{q i}+\alpha_{2} \cdot D+\alpha_{3} \cdot\left(D \cdot S_{q i}\right)+\varepsilon
$$

where $S_{i} \equiv 2 \cdot \sqrt{-\operatorname{cov}\left(R D_{i t}, R D_{i t-1}\right)} ; R D_{i t} \equiv R_{i T t}-R_{i B t}, R_{i T t}$ is the continuously compounded transaction return on security $i$ in period $t$ and $R_{i B t}$ is the continuously compounded return from bid quotes following transaction prices; $S_{q i}$ is the quoted spread on security $i ; D$ is +1 if the stock is quoted on the NASDAQ and 0 if listed on NYSE. The most commonly used methodology to investigate the bid-ask spread follows Glosten and Harris (1988), Stoll (1989), and George, Kaul and Nimalendran (1991). However, new studies are refining the decomposition of the bid-ask spread to examine the observed patterns of spread revisions. ${ }^{7}$ (see Krinsky and Lee (1996) and Affleck-Graves et al. (1994))

\section{B. Transaction Process}

The observed price changes are not independent because transactions happen at either bid or ask prices, therefore, negative serial dependence in observed transaction prices is anticipated. Roll (1984) uses the following argument for negative serial covariance. Consider the development in the bid-ask spread $S$ at time $t_{0}$, the ask and bid prices are $P_{o}^{a}$ and

\footnotetext{
${ }^{7}$ Glosten and Harris (1988) measures the bid-ask spread by the sum of the order-processing and adverse selection components and both components are a linear function of the transaction size. George, Kaul and Nimalendran (1991) allow the expected ret urns to be serially dependent.
} 
$P_{o}^{b}$, respectively, assuming that all transactions are constant at $S$. The transaction price arrives randomly within the quoted bid-ask spread and they are equally likely. The quoted spread may be different than the effective or realized bid-ask spread. Thus, price changes occur only if unanticipated information arrives to the marketplace, i.e. with no new information there will be no serial covariance in price changes $\left(\Delta P_{t} \equiv P_{t}-P_{t-1}\right)$. If $P^{v}$ is fixed, a constant bid-ask bounce, and the quoted prices can only take two values then the changes in the fundamental value, $P_{t}^{v}$, displays only volatility and negative serial correlation. If the current transaction price is the ask price $P_{a}$ (the bid price, $P_{b}$ ) then a price change between $P_{t}$ and $P_{t-1}$ is 0 or s $(0$ or $+\mathrm{s})$. The next price change between $P_{t+1}$ and $P_{t}$ is 0 or $-\mathrm{s}(0$ or s). Thus, the probability distribution for successive price changes that is conditioned on no new information, is dependent on whether the last transaction was at the bid or the ask price. Roll (1984) shows that the variance of the observed prices is domi nated by new information while the covariance does not dependent on new information assuming efficient markets. Also, the spread-induced serial covariance is independent of the time increments in successive prices. Therefore, following Roll's assumption of a constant spread, the bid and ask prices will always bounce symmetrically around the fundamental price, i.e. the spread reflects only order-processing costs. Stoll (1989) modifies the possible paths of observed market prices to adjustments for inventory-holding costs and adverse-selection costs.

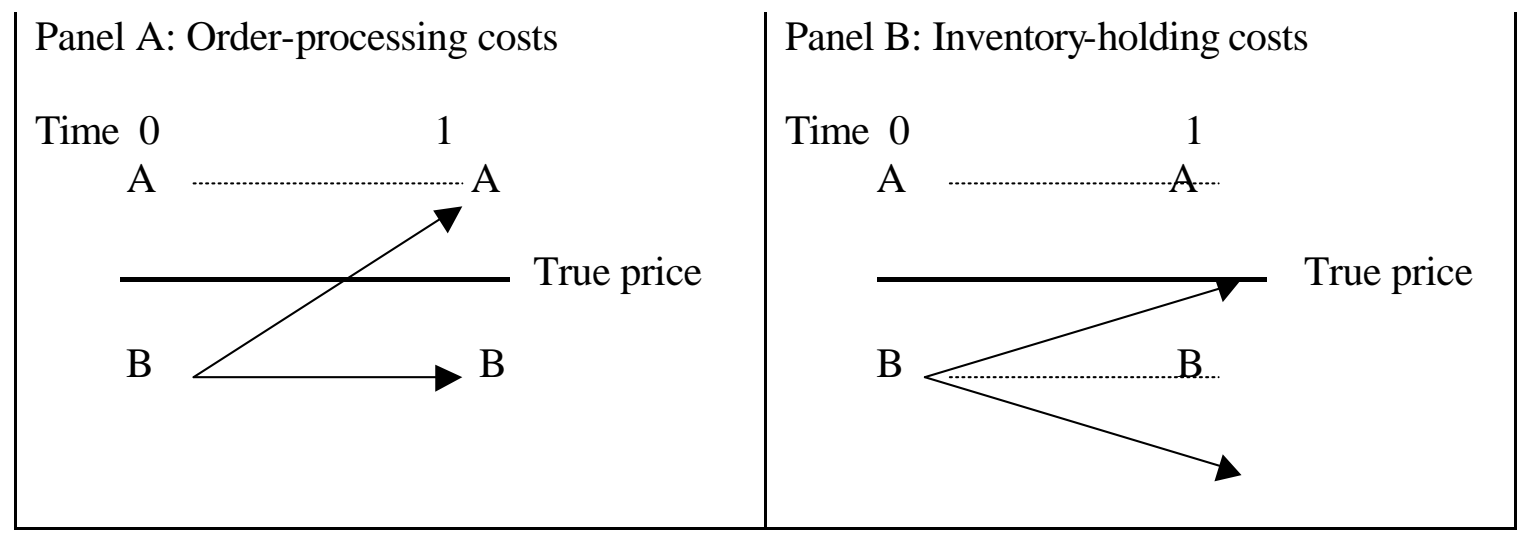




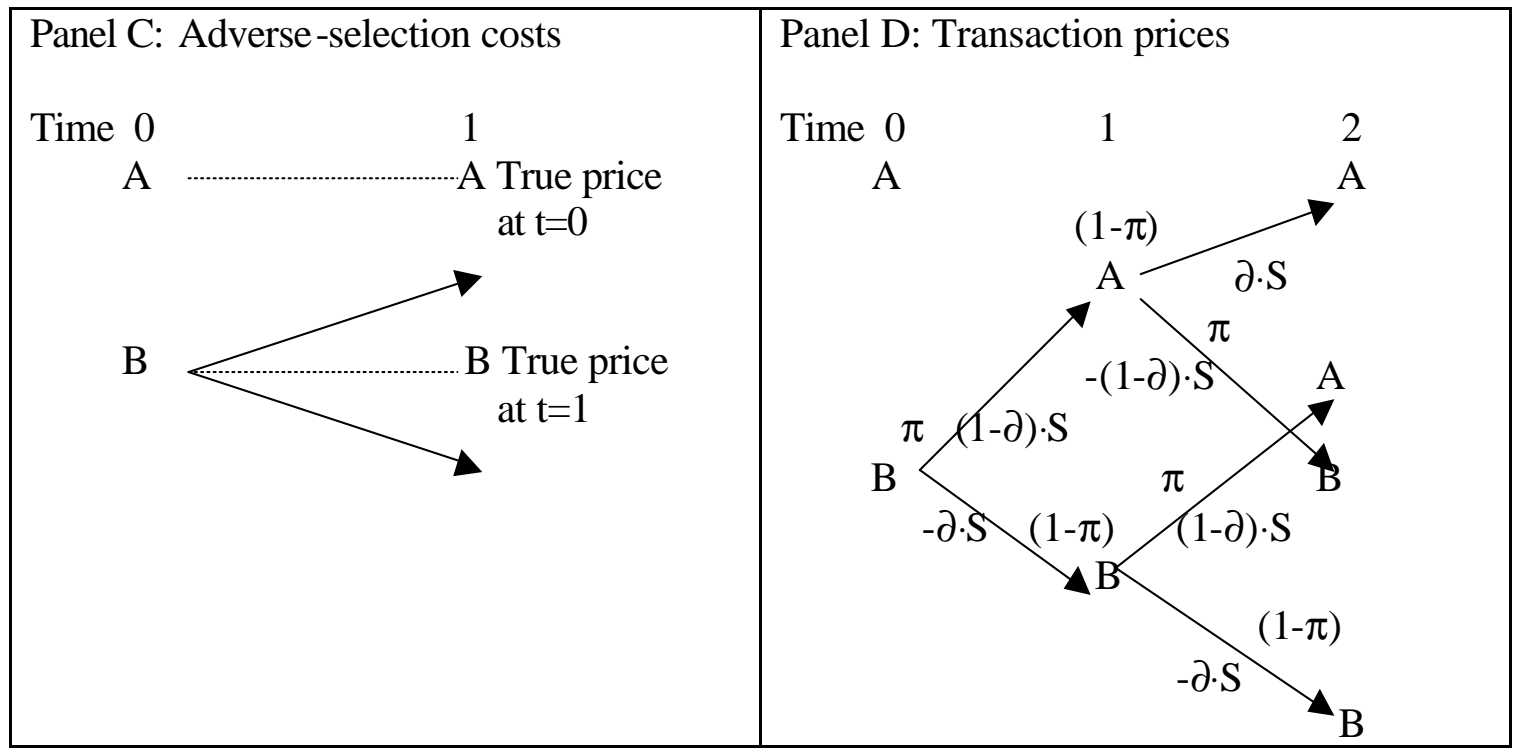

Panel A is similar to Roll's (1984) description of the bid-ask spread that follows a naï ve order-processing costs model. Panel B shows the inventory-holding costs as reflected by the spread. Based on these models, the market makers tend to changes the spread relative to the fundamental price so that their inventories are maintained around a preferred level. Stoll (1989) argues that new transaction prices are determined in such a way that market makers are indifferent between bid or ask transactions and the inventory-holding costs move symmetrically around the initiated trade price. This leaves the market maker with $0.5 \cdot S$, if a trade is reversed. Panel $\mathrm{C}$ reflects the spread from the adverse-selection costs, which moves similarly to the inventory-holding costs. The reason is that the transaction at bid (ask) indicate that the expected equilibrium price is lower (higher). But, the price change assumes that traders possess superior information. The expected spread, $\left(P_{o}^{a}-\right.$ $\left.P_{o}^{b}\right) / 2$, changes when a transaction conveys information to the market makers, who revise the expected equilibrium price to $\left(P_{1}^{a}-P_{1}^{b}\right) / 2$. Stoll (1989) argues that the realized spread is smaller than the market makers' quoted spread because it depends only on adverseselection costs and inventory-holding costs.

Stoll (1989) extended Roll's (1984) model of the bid-ask spread by estimating the probabilities of price reversal and the magnitude of the price changes. Panel D shows all pos- 
sible sequences of transaction prices starting at the bid price. The price continuation is $\partial \cdot S$ and the size of the price reversal is $(1-\partial) \cdot S$, where $\partial$ is between zero and one. The probability of a price reversal is $\pi$ and a continuation is $(1-\pi)$ and the covariance of transaction prices and quoted prices are:

$$
\begin{aligned}
& \operatorname{Cov}_{\mathrm{p}} \equiv \operatorname{cov}\left(\Delta P_{t}^{p}, \Delta P_{t+1}^{p}\right) \quad=\mathrm{S}^{2}\left[\partial^{2} \cdot(1-2 \pi)-\pi^{2} \cdot(1-2 \partial)\right] \\
& \operatorname{Cov}_{\mathrm{a}, \mathrm{b}} \equiv \operatorname{cov}\left(\Delta P_{t}^{a, b}, \Delta P_{t+1}^{a, b}\right)=\mathrm{S}^{2} \cdot \partial^{2} \cdot(1-2 \pi)
\end{aligned}
$$

With a constant spread the serial covariance for bid prices is equal to the serial covariance for ask prices. ${ }^{8}$ Empirical findings show that the probability of a reversal is greater than 0.5 and that the size of the price reversal $\partial$ less than or equal to 0.5. Roll (1984) assumes that $\partial$ is equal to 0.0 and $\pi$ is equal to 0.5 in the order processing model while Copeland and Galai (1983) and Glosten and Milgrom (1985) use $\partial$ equal to 0.5 and $\pi$ greater than 0.5 in their adverse selection model. In the pure inventory holding model by Ho and Stoll (1985) $\partial=0.5$ and $1>\pi>0$.

\section{Data Material and Empirical Estimation}

\section{A. Data Material}

Earnings announcements are shown to convey new (positive or negative) information and the events are reasonably predictable. The data material provides evidence on whether uninformed market makers believe that earnings announcements increase the information asymmetry. Pre-event, event, and post-event periods are analyzed to confirm whether informed traders utilize information uncertainty prior to earnings releases. The pre-event window is from 45 days to 16 days before an earnings announcement. The event window is from 15 days before to 15 days after an announcement and the post-event window is 16

\footnotetext{
${ }^{8}$ The serial covariance equations are derived from the transaction process. In Roll (1984) and Stoll (1989) a formal proof is derived. Roll (1984) shows that when $\partial$ is 0 and $\pi$ is 0.5 then the $\operatorname{cov}_{p}$ equals $0.25 \cdot S^{2}$. Stoll (1989) shows that the total change in security prices equals the price changes due to the spread.
} 
days to 45 days after an earnings announcement. The data set includes transaction prices, price quotations, and annual earnings announcements for firms on the Copenhagen Stock Exchange between 1989 and 1996. A total of 976 earnings announcements are identified. The earnings announcements and the pricing data are gathered from Datastream. ${ }^{9}$ The transaction prices are the daily closing prices and quoted prices are the bid and ask prices. But the analysis only includes observations when daily bid-ask quotes can be matched against the closing transaction price.

\section{[INSERT TABLE I]}

The summary statistics presented in table I show the differences between event periods in the mean serial covariance, the share price, the trading volume, the turnover ratio, and the market values. $\operatorname{Cov}_{b}, \operatorname{Cov}_{a}$, and $\operatorname{Cov}_{p}$ are serial covariance of daily closing bid, ask and transaction prices. $S$ is the average proportional bid-ask spread. Price is the crosssectional average stock price in the event window. Volume is the average volume of trading in the event window. The turnover variable is the average cross-sectional turnover ratio in each event window. Market value is the average market value for the sample of firms included in the analysis.

Comparable to the findings of Krinsky and Lee (1996), the traded number of outstanding shares times transaction prices and the turnover ratio (the number of shares traded divided by the outstanding shares) increases around earnings announcements. Although, difference in mean between periods are not statistically significant at any level. Admati and Pfleiderer (1988) argue that an increase in trading volume will induce lower adverse selection while Foster and Viswanathan (1990) argue that an increase in volume will induce more information asymmetry. Therefore, the observed increase in volume may have significant impact on the adverse-selection cost in the bid-ask spread. The proportional spread in-

\footnotetext{
9 Transaction and quoted prices are gathered when available for earnings announcements. A major disadvantage of the data set is that it is not possible to gather intra-day transaction prices. Krinsky and Lee (1996) estimate $\operatorname{cov}_{\mathrm{p}}$ on the latest transaction price in each half-hour interval while Stoll (1989) and Affleck-Graves, Hedge and Miller (1994) require each stock to have a minimum of three transactions on at least fifteen trading days in each month.
} 
creases significantly at a 5 percent level between the event window and the post-event window. The bid-ask spread between the pre-event and event windows does not increase significantly. Krinsky and Lee (1996) argue that the earnings announcement may still have an impact on the information asymmetry because of the individual components in the bidask spread. The difference between serial covariance of transaction prices for each period is not statistically significant. However, the serial covariance of the quoted bid and ask prices experiences a significant increase from the pre-event window to the event and postevent windows. An interpretation of the wider spread around earnings announcements may be that the market makers suspect an increased level of information asymmetry. Jaffe and Winkler (1976) show that firm-specific information may lead to greater information asymmetry, i.e. changes in the trading behavior by informed and uninformed market participants. A wider bid-ask spread offsets higher expected losses to the market makers for trading with informed investors. The next section investigates the magnitude of the bid-ask spread components.

\section{B. Empirical Estimation}

Regressions [6,7] are used to estimate the price continuation parameter $\partial$ and the probability for a price reversal $\pi$. The adverse-selection, the inventory-holding, and the orderprocessing components of the spread are estimated from the serial covariance on the squared bid-ask spread. The estimated parameters are obtained for each period by averaging the estimates of the OLS coefficients of $\alpha_{l}$ and $\beta_{l}$. The proportional spread is based on serial covariance of the difference in transaction returns and the returns from bid-bid and ask-ask prices. Using returns instead of price differences eliminates autocovariance in time-varying expected returns (George et al. 1991).

$$
\begin{aligned}
& \operatorname{Cov}_{p}=\alpha_{b}+\alpha_{l} \cdot S^{2}+u \\
& \operatorname{Cov}_{a, b}=\beta_{b}+\beta_{l} \cdot S^{2}+v
\end{aligned}
$$


where $S$ denotes the quoted proportional spread as the difference between the ask and bid prices, divided by the average of the ask and the bid; $\operatorname{cov}_{p}$ is the serial covariance of the returns of the transaction closing prices; $\operatorname{cov}_{a, b}$ is the serial covariance of the returns of the bid and ask prices; $u, v$ are random errors. The intermediate values of $\partial$ and $\pi$ are found from two auxiliary equations that provide the three components that are used to estimate the magnitude of the bid-ask spread.

$$
\alpha_{l}=\partial^{2} \cdot(1-2 \cdot \pi)-\pi^{2} \cdot(1-2 \cdot \partial) \text { and } \beta_{1}=\partial^{2} \cdot(1-2 \cdot \pi)
$$

Stoll (1989) made three empirical assumptions for $\pi$ and $\partial: 1)$ the market is efficient in the sense that the expected price changes in a security is independent of current and past information; 2 ) the spread, $S$, is constant over the analyzed period of one-month; ${ }^{10} 3$ ) all transactions are carried out at the highest bid and or at the lowest ask price available in the market. Based on these assumptions the three components of the bid-ask spread are determined as:

$$
\begin{array}{ll}
\text { Adverse-selection costs: } & {[1-2 \cdot(\pi-\partial)]} \\
\text { Inventory-holding costs: } & 2 \cdot(\pi-0.5) \\
\text { Order-processing costs: } & (1-2 \cdot \partial)
\end{array}
$$

Stoll's (1989) method provides estimates of the amount charge in cents for each component of the spread per dollar of stock price. Multiplying the proportional components of the percentage-spread shows the costs per dollar of price. Table II shows the results of serial covariance against the squared proportional bid-ask spread for the pre-event, event, and postevent window.

\section{[INSERT TABLE II]}

\footnotetext{
${ }^{10}$ This assumption may be relaxed to allow for random variations in the spread.
} 
The estimation parameters $\alpha_{l}$ and $\beta_{l}$ are from $\operatorname{cov}_{a, b}=\beta_{0}^{a, b}+\beta_{1}^{a, b} \cdot S^{2}+\varepsilon^{a, b}$ and $\operatorname{cov}_{p}=\beta_{0}^{a, b}+\beta_{1}^{a, b} \cdot S^{2}+\varepsilon^{p}$, respectively. Panel A shows bid prices, panel B shows ask prices, and panel $\mathrm{C}$ shows transaction prices. The estimated $\alpha_{l}$ coefficients are all negative and statistically significant. Similar to the findings in Stoll (1989), this result confirms the expectation of the implied spread, i.e. $\operatorname{cov}_{p} \leq 0.0$. The overall value of $\alpha_{1}$ is based on the serial covariance between daily closing prices. It is $-0.117,-0.072$, and -0.129 in the pre-event, event, and post-event window, respectively. The squared bid-ask spread explains the cross-sectional variation of the serial covariance at 4.39 percent, 1.97 percent, and 20.12 percent in the pre-event, event, and post-event window, respectively. The estimated value of $\beta_{l}$ is the average coefficient from panel $A$ and $B$, and it is based on the serial covariance of the bid and the ask prices. The $\beta_{l}$ coefficients are all negative and statistically significant in four of the six estimations. The negative values support the inventoryholding cost explanation (Stoll, 1989).

Under the assumption of the market efficiency hypothesis, the expected value of $\alpha_{0}$ and $\beta_{0}$ is 0.0. However, the estimated values are significant in six of the nine regressions. From the transaction prices, $\alpha_{0}$ is small and positive, while from the bid and ask prices, $\beta_{0}$ is small and negative. Stoll (1989) argues that positive intercepts may reflect a form of market efficiency due to a delay in price adjustments. The negative intercepts may reflect the differences in actual transaction sizes that exceed transactions that are implied in the quoted bid-ask spread.

Roll (1984) shows that the implied spread is related to firm size and Stoll (1989) shows that the quoted spread is related to volume of trading, the stock price, the number of market makers, and the underlying risk of the security. Affleck-Graves et al (1994) argue that important characteristics of the bid-ask spread are the structure of trading and stock specific characteristics. The relationship between the quoted and realized spread is examined with the following equations: 


$$
\begin{aligned}
& \operatorname{cov}_{\mathrm{p}}=\alpha_{0}+\alpha_{1} \cdot S^{2}+\alpha_{2} \cdot S^{2} \cdot X \\
& \operatorname{cov}_{\mathrm{a}, \mathrm{b}}=\beta_{0}+\beta_{1} \cdot S^{2}+\beta_{2} \cdot S^{2} \cdot X
\end{aligned}
$$

where $a_{1}=\alpha_{1}+\alpha_{2} \cdot X$ and $b_{1}=\beta_{1}+\beta_{2} \cdot X$. The variables to explain serial covariance are the average stock price, the average daily volume divide by outstanding shares, the turnover ratio the average daily volume divided by outstanding shares, and the average market value. ${ }^{11}$ The turnover ratio reflects the degree of informational trading and therefore, reflects the adverse-selection costs (Stoll, 1989). It is expected that the transition from the pre-event to the event period around earnings announcements increases the information asymmetry. Stoll (1989) argues that in the absence of information asymmetry, trading happens in proportions to the outstanding amount.

Table III summaries the regression results, and similar to Stoll (1989), it appears that the stock characteristics do not influence the estimation parameter, $\alpha_{1}$. The results show that the cross-sectional difference is reflected in the spread and not in the transaction price parameters. Similar to Stoll (1989) it is evident that the parameter $\alpha_{1}$ is not dependent on the stock characteristics. The positive turnover ratio may imply that the greater the turnover, the less the serial covariance. But, the turnover ratio is not statistically significant.

\section{[INSERT TABLE III]}

The stock price coefficient in $\operatorname{cov}_{\text {price }}$ is negative and statistically significant while the coefficient in $\operatorname{cov}_{a, b}$ is only significant and negative in one of six regressions. The negative coefficient implies that higher stock prices lead to higher negative covariance. Stoll (1989) finds positive coefficients and argues that this may imply greater adverse-information costs in higher-priced stocks.

\footnotetext{
${ }^{11}$ A similar setup is proposed in Stoll (1989) but there is no theoretical justification for the chosen variables except turnover ratio.
} 


\section{The Magnitude of the Bid-Ask Components}

\section{A. Change in Bid-Ask Components Around Earnings Announcements}

Panel A of table IV summaries the adverse-selection, inventory-holding, and orderprocessing costs in proportion to the bid-ask spread percentage. The results indicate that the information asymmetry changes around earnings announcements. The adverse-selection costs increase from 55 percent to 72 percent of the quoted proportional spread. Following earnings announcements in the post-event window, the adverse-selection costs decrease to 51 percent. The difference in the components between the event and pre-event windows and post-event and event windows is 16.4 percent and -20.6 percent. Consistent with the findings in Krinsky and Lee (1996), the results suggest that in a thirty-day window the information asymmetry increase around the earnings announcement. The results suggest that earnings announcements provide important pricing information, which supplies the informed traders with information advantages over the market makers. The findings in Kim and Verrecchia (1994) and Krinsky and Lee (1996) suggest similar results, but the information disadvantage does not induce the market makers to increase the bid-ask spread.

\section{[INSERT TABLE IV]}

The auxiliary equations are nonlinear transformations of the estimation parameters and the distribution of the spread components is unknown, therefore, a bootstrapping technique is applied. The bootstrapping method by Affleck-Graves et al. (1994) and Krinsky and Lee (1996) is applied to make inference of the difference between each window. ${ }^{12}$ Furthermore, the distribution of the components is affected by $\operatorname{cov}_{p}$, which may not be independent of $\operatorname{cov}_{a, b}$ and the parameters may not be independent (Affleck-Graves et al, 1994).

The results in table IV show that inventory-holding costs around earnings announcements are reduced to 18.9 percent from 26.7 percent in the pre-event window however, the de-

\footnotetext{
${ }^{12}$ The appendix in Affleck-Graves et al (1994) provide an excellent description of the applied bootstrapping technique that is used to estimate $p$-values of whether or not the components of the spread are significant different between periods.
} 
crease is not statistically significant at any level. The inventory-holding costs increase 12.28 percent after the event window, which may be due to the increase in volume and the turnover. Krinsky and Lee (1996) argue that higher volume induces the market makers to tighten the spread because of economics of scale, while the increase in volatility induces wider spread, because of the risk of holding inventory. The order-processing cost declines from 17.9 percent in the pre-event window to 9.3 percent in the event window however, the decrease is not statistically significant at any level. It seems that the inventory-holding and order-processing costs move together. The reduction in the realized spread may not be reflected in the changes in the quoted spread. The realized spread is the expected price change from a purchase minus a sale, i.e. the spread is $2 \cdot(\pi-\partial) \cdot S$. This spread represents, the market makers expected profit but the change in the realized spread indicates a decrease in the market makers realized profit. The cost per dollar of price estimates shown in panel B are obtained by multiplying the proportional spread with the mean percentage spread, similar to the methodology used by Affleck-Graves, Hedge, and Miller (1994). The change in cost per dollar moves similarly to the cost component, but the magnitude depends on the average cross-sectional spread for each window. The adverse-selection costs of an average stock price at 486.12 (DKK) during the post-event window (see table I) decreases by $57.75(D K K)$. The average realized spread increases by $281.89(D K K)$ per round trip transaction.

Table IV shows an increase in the adverse-selection cost that is caused by the information asymmetry. The market values change the components of the spread because they face informed traders. The trading volume increases around the earnings announcements however, the increase is not statistically significant, which Krinsky and Lee (1996) argue reduces the realized spread. George et al. (1991) finds no evidence of an inventory-holding cost. This may be explained by the difference in the time period. Stoll (1989), Affleck-Graves et al. (1994) use three months and two months, respectively, while George et al. (1991) uses a time horizon of five years. ${ }^{13}$ Around earnings announcements the inventory-holding cost is a

\footnotetext{
${ }^{13}$ Roll (1984) and Glosten (1987) shows that different interval used to measure serial covariance does not affect estimates of the order-processing costs or the adverse-selection costs. Greoge et al. (1991) argues that high frequency data is more appropriate because autocovariance-based spread suffer from
} 
significant part of the quoted spread. Krinsky and Lee (1996) find that the adverseselection cost increase significantly form 59.5 percent to 76.4 percent from the pre-event window to the event window. The inventory-holding and order-processing costs decrease approximately by 10 percent. This lead Krinsky and Lee (1996) to conclude that earnings announcements may have an insignificant impact on the total spread but it may increase information asymmetry. Stoll (1989) finds an adverse-selection cost of 47 percent, which is similar to Krinsky and Lee (1996) in their benchmark period. In contrast, Venkatesh and Chiang (1986) find no increase in the information asymmetry but if the earnings announcement is followed by another announcement the information asymmetry increases significantly. This suggests that non-normal information asymmetry exists before earnings announcements. Affleck-Graves et al. (1994) find that the adverse-selection cost is 50 percent on NYSE and it is 36 percent on NASDAQ. The inventory-holding cost is 47 percent for NYSE and 17 percent for NASDAQ. The order-processing cost is 1 percent for NYSE and 47 percent NASDAQ. Comparing the NYSE to the NASDAQ indicates that the adverseselection and the order-processing costs significantly influence the trading structure. It may be due to the auction-based trading on the NYSE and the multiple dealers on the NASDAQ.

\section{B. Positive and Negative Earnings Surprises}

In the information asymmetry model, consistent with the liquidity traders and the informed traders, the market makers carry losses from trading with informed traders. The information that the informed traders trade on is not currently reflected in the prices, therefore, the market makers may recover potential losses through the bid-ask spread. Thus, the expectation is that the information asymmetry among the market participants induces a wider spread. Hence, partitioning the announcements into two groups, one with positive earnings surprises and a second with negative earnings surprises, to estimate the magnitude and the changes in the adverse-selection, inventory-holding, and order-processing components.

\section{[INSERT TABLE V]}

small-sample bias, i.e. the difference time interval significantly effects estimators of the spread and its 
Panel A in table V shows that the components in the realized spread change significantly between the pre-event window and the event window. The inventory-holding cost increases from 15.9 percent to 25.5 percent, which implies that the market makers are holding more non-preferable inventory to maintain their liquidity service. To outweigh the inventory-holding costs, the market makers reduce the order-processing costs. However, the realized spread does not change for the group of positive earnings surprises. This may imply that less information asymmetry among market participants exists around positive earnings surprises. The cost per dollar of price for positive earnings surprises in panel B shows an increase in the inventory-holding costs and a decrease in the order-processing costs. The economic magnitude implies that the adverse-selection costs for an average stock price of $D K K 538.25$ for positive earnings surprises decreases by $D K K 3.45$ ( $\phi r e$ ) during the event window. The average realized spread increases by $D K K 76.59$ ( $\phi r e)$ per round-trip transaction.

Panel C in table V shows that the information asymmetry increases significantly among the market participants between the pre-event window, the event window, and the post-event window for negative earnings surprises. The negative 20.2 percent decrease in inventoryholding costs implies that the market makers hold less inventory in which information asymmetry exists. Between the event window and the post event window, the inventoryholding cost is reversed. This implies that the change in the realized spread is temporary in the event window. In addition, the decrease from 69.5 percent to 37.2 percent in the realized spread (or gross profit) from pre-event window to event window implies that it is costly for the market makers when trading with informed market participants.

The cost per dollar of price for negative earnings surprises in panel D shows a decrease in the inventory-holding costs and a decrease in the order-processing costs. This implies that the transaction costs change significantly. The economic magnitude implies that the adverse-selection costs for an average stock price of $D K K 452.46$ for negative earnings sur-

components. 
prises increased by $D K K 2.26$ during the event window. The average realized spread declined by DKK 2.26 per round trip transaction. As Krinsky and Lee (1996) argue, the magnitude of the change in the realized spread appears to be important but the change in the total spread is negligible.

Overall, the results in table $\mathrm{V}$ show an increasing and significant adverse-selection cost around negative earnings surprises. The component represents 62.9 percent (30.5 percent) of the quoted proportional spread for the event (pre-event) window. This implies considerable information asymmetry among market participants and more information uncertainty around negative earnings surprises than around positive earnings surprises. One possible explanation is that earnings information that is below expected creates uncertainty among market participants. Similar to Krinsky and Lee (1996), the results show support for the hypothesis that the adverse-selection costs of the bid-ask spread increases. The interpretation of the increase is that it occurs because of a higher probability that a market maker is trading with an informed trader with superior information. But, the results do not show support for Krinsky and Lee's (1996) hypothesis that the adverse-selection component increases following the announcement. The results suggest that the information asymmetry after the earnings announcement return to the level of the pre-event window. This implies that the informed traders' ability to assess firms' performance only affect the bid-ask spread in the event window around earnings announcements.

\section{Conclusion}

The changes in the bid-ask spread components around earnings announcements show that earnings surprises convey relevant pricing information and that significant informational asymmetry exists between market makers and informed traders. The adverse-selection component and the trading volume increase while the inventory-holding component and the order-processing component decreases around earnings announcements. The results show an increase in the information asymmetry and that the informed traders have an informa- 
tional advantage over market makers. But, the market makers informational disadvantage does not induce an increase in the quoted bid-ask spread.

Partitioning the earnings announcements into positive surprises and negative surprises shows that the realized bid-ask spread does not change for good surprises while for bad surprises the information asymmetry increase significantly. The results imply that less information asymmetry exists among market participants around positive earnings surprises. The change in the spread for negative earnings surprises is temporary in the event window, implying that it is costly for market makers when trading with informed market participants. A possible explanation of the different market responds to positive and negative earnings surprises may be that firms announcing earnings below expectations creates uncertainty among market participants. The economic magnitude of changes in the adverse-selection component for earnings announcements is comparable to the change in the inventoryholding and the order-processing components. The quoted spread does not change significantly despite the fact that the information asymmetry increases around earnings announcements. The overall results may be interpreted as evidence of temporary increased information asymmetry. 


\section{References}

Affleck-Graves, J., S. P. Hedge and R. E. Miller, 1994, Trading mechanisms and the components of the bid-ask spread, Journal of Finance 49, 1471-1488.

Cambell, John, Y., Andrew W. Lo, and A. Craig MacKinlay, 1997, The Economics of Financial Markets, Princeton University Press

Copeland, T. and D. Galai, 1983, Information effects on the bid-ask spread, Journal of Finance 38, 1457-1469.

Foster, F. G. and S. Viswanathan, 1993, Variation in trading volume, return volatility, and trading costs: Evidence on recent price formation models, Journal of Finance 48, 187211.

George, T. H., G. Kaul, and M. Nimalendran, 1991, Estimation of the bid-ask spread and its components: A new approach, Review of Financial Studies 4, 623-656.

Glosten, L. R. and P. R. Milgrom, 1985, Bid, ask, and transaction prices in specialist market with heterogeneously informed traders, Journal of Financial Economics 14, 71-100.

Ho, T., and H. Stoll, 1981, Optimal dealer pricing under transaction and return uncertainty, Journal of Financial Economics 10, 47-74.

Kim, O., and R. E. Verrecchia, 1994, Market liquidity and volume around earnings announcements, Journal of Accounting and Economics 17, 41-67.

Krinsky, I. and J. Lee, 1996, Earnings Announcements and the Components of the Bid-Ask Spread, Journal of Finance 51, 1523-1534.

Stoll, H. R., 1989, Inferring the components of the bid-ask spread: Theory and empirical tests, Journal of Finance 44, 115-134.

Venkatesh, P. C., and R. Chiang, 1986, Information asymmetry and the dealer's bid-ask spread: A case study of earnings and dividend announcements, Journal of Finance 41, 1089-1102. 
Table I

\section{Descriptive Statistics}

The sample includes earnings announcements from firms on the Copenhagen Stock Exchange between 1989 and 1996. The pre-event window is from 45 days to 16 day before an earnings announcement. The event window is from 15 days before to 15 days after an announcement. The post-event is 16 to 45 days after earnings announcement. $C_{b} v_{b}$, Cov $_{a}$, and Cov $_{p}$ are serial covariance of daily closing bid, ask and transaction price. $S$ is the average proportional quoted bid-ask spread. Price is the cross-sectional average stock price for each event window. Volume is the average trading volume in the month. Turnover is the average cross-sectional turnover ratio for each period. Market value is the average market value of the firms in the sample. t-statistics are shown in parentheses.

\begin{tabular}{|c|c|c|c|c|c|c|c|c|c|}
\hline \multirow{2}{*}{$\begin{array}{l}\text { Panel A } \\
\text { Sample size } \\
\text { Panel B } \\
\text { Variable }\end{array}$} & \multicolumn{2}{|c|}{$\frac{\text { Pre-event }}{\mathrm{N}=606}$} & \multicolumn{2}{|c|}{$\frac{\text { Event }}{\mathrm{N}=595}$} & \multicolumn{2}{|c|}{$\frac{\text { Post-event }}{\mathrm{N}=597}$} & \multicolumn{3}{|c|}{ Difference } \\
\hline & Mean & Std & Mean & Std & Mean & Std & $\begin{array}{c}\text { Event - } \\
\text { pre e vent }\end{array}$ & $\begin{array}{l}\text { Post - } \\
\text { Event }\end{array}$ & $\begin{array}{c}\text { Post - } \\
\text { Pre event }\end{array}$ \\
\hline $\operatorname{Cov}_{p}$ & -0.2604 & 6.0997 & -0.2267 & 4.5169 & -0.5493 & 3.9977 & $\begin{array}{c}0.0337 \\
(0.11)\end{array}$ & $\begin{array}{c}-0.3226 \\
(-1.31)\end{array}$ & $\begin{array}{c}-0.2888 \\
(-0.97)\end{array}$ \\
\hline $\operatorname{Cov}_{a}$ & -0.3582 & 2.2584 & -1.0416 & 5.4918 & -1.3333 & 4.4319 & $\begin{array}{l}-0.6833 \\
(-2.84)^{\mathrm{a}}\end{array}$ & $\begin{array}{c}-0.2918 \\
(-1.01)\end{array}$ & $\begin{array}{l}-0.9751 \\
(-4.84)^{\mathrm{a}}\end{array}$ \\
\hline Cov & -0.5162 & 4.4649 & -0.8699 & 4.0187 & -1.1401 & 5.9932 & $\begin{array}{c}-0.3536 \\
(-1.45)\end{array}$ & $\begin{array}{c}-0.2703 \\
(-0.91)\end{array}$ & $\begin{array}{l}-0.6239 \\
(-2.05)^{\mathrm{a}}\end{array}$ \\
\hline Spread, \% & 1.72 & 1.44 & 1.72 & 1.34 & 2.18 & 1.56 & $\begin{array}{c}0.00 \\
(0.04)\end{array}$ & $\begin{array}{c}0.46 \\
(3.31)^{\mathrm{a}}\end{array}$ & $\begin{array}{c}0.46 \\
(3.31)^{\mathrm{a}}\end{array}$ \\
\hline Price & 496.18 & 562.46 & 494.27 & 582.60 & 486.12 & 552.24 & $\begin{array}{l}-1.92 \\
(-0.06)\end{array}$ & $\begin{array}{l}-8.15 \\
(-0.26)\end{array}$ & $\begin{array}{r}-10.07 \\
(0.33)\end{array}$ \\
\hline Volume & 16.18 & 36.48 & 19.62 & 50.01 & 15.74 & 35.17 & $\begin{array}{c}3.44 \\
(-1.25)\end{array}$ & $\begin{array}{l}-3.88 \\
(-1.34)\end{array}$ & $\begin{array}{l}-0.44 \\
(-0.12)\end{array}$ \\
\hline $\begin{array}{l}\text { Turnover Ratio } \\
\%\end{array}$ & 5.20 & 11.47 & 6.06 & 13.43 & 5.18 & 11.11 & $\begin{array}{c}0.87 \\
(1.10)\end{array}$ & $\begin{array}{l}-0.88 \\
(-1.07)\end{array}$ & $\begin{array}{c}-0.01 \\
(-0.05)\end{array}$ \\
\hline Market value & 2121.95 & 3980.06 & 2123.94 & 4128.15 & 2161.40 & 4075.05 & $\begin{array}{c}1.99 \\
(0.01) \\
\end{array}$ & $\begin{array}{l}37.46 \\
(0.29) \\
\end{array}$ & $\begin{array}{l}39.44 \\
(0.31) \\
\end{array}$ \\
\hline \multicolumn{10}{|l|}{ Panel C } \\
\hline $\begin{array}{l}\text { Spread, \% - Posi- } \\
\text { tive }\end{array}$ & 1.55 & 1.17 & 1.61 & 1.11 & 2.10 & 1.49 & $\begin{array}{l}0.06 \\
(0.59)\end{array}$ & $\begin{array}{c}0.49 \\
(4.34)^{\mathrm{a}}\end{array}$ & $\begin{array}{c}0.55 \\
(4.77)^{\mathrm{a}}\end{array}$ \\
\hline $\begin{array}{l}\text { Spread, \% - Nega- } \\
\text { tive }\end{array}$ & 1.96 & 1.63 & 1.91 & 1.54 & 2.30 & 1.65 & $\begin{array}{l}-0.05 \\
(-0.39)\end{array}$ & $\begin{array}{c}0.38 \\
(2.83)^{\mathrm{a}}\end{array}$ & $\begin{array}{c}0.33 \\
(2.39)^{\mathrm{a}}\end{array}$ \\
\hline $\begin{array}{l}\text { Price - } \\
\text { Positive }\end{array}$ & 528.23 & 614.56 & 538.46 & 675.47 & 506.52 & 597,35 & $\begin{array}{l}10.01 \\
(0.18)\end{array}$ & $\begin{array}{l}-31.72 \\
(-0.58)\end{array}$ & $\begin{array}{l}-21.71 \\
(-0.42)\end{array}$ \\
\hline $\begin{array}{l}\text { Price - } \\
\text { Negative }\end{array}$ & 453,23 & 505,39 & 452,46 & 494,08 & 459,77 & 508,48 & $\begin{array}{c}-0,77 \\
(-0.02) \\
\end{array}$ & $\begin{array}{c}7.31 \\
(0.17) \\
\end{array}$ & $\begin{array}{c}6.54 \\
(0.15) \\
\end{array}$ \\
\hline
\end{tabular}

${ }^{\mathrm{a}, \mathrm{b}}$ Indicate statistically significance at the 5 and 1 percent level, respectively. 



\section{Table II Regression results}

Regression of serial covariance against the squared proportional bid-ask spread for the pre-event, event, and post-event window. $\operatorname{Cov}_{b}, \operatorname{Cov}_{a}$, and $\operatorname{Cov}_{p}$ are serial covariance of daily closing bid, ask and transaction price. $S$ is the average proportional bid-ask spread. The estimation parameters $\alpha_{1}$ and $\beta_{1}$ are from $\operatorname{cov}_{a, b}=\beta_{0}^{a, b}+\beta_{1}^{a, b} \cdot S^{2}+\varepsilon^{a, b}$ and $\operatorname{cov}_{p}=\alpha_{0}^{p}+\alpha_{1}^{p} \cdot S^{2}+\varepsilon^{p}$, respectively. Panel $\mathrm{A}$ is for bid prices, panel $\mathrm{B}$ is for ask, and panel $\mathrm{C}$ is for transaction prices. $\mathrm{t}$-statistics are shown in parentheses.

\begin{tabular}{|c|c|c|c|c|}
\hline Panel A: Bid & $\begin{array}{l}\text { Dependent } \\
\text { Variable }\end{array}$ & $\beta_{0}$ & $\beta_{1}$ & $\mathrm{R}^{2}$ \\
\hline Pre-event & $\operatorname{Cov}_{b}$ & $\begin{array}{c}-0.000022 \\
(-1.13)\end{array}$ & $\begin{array}{c}-0.058436 \\
(-3.56)\end{array}$ & 0.0205 \\
\hline Event & $\operatorname{Cov}_{b}$ & $\begin{array}{c}-0.000069 \\
(-3.68)\end{array}$ & $\begin{array}{c}-0.038617 \\
(-2.06)\end{array}$ & 0.0071 \\
\hline Post-event & $\operatorname{Cov}_{b}$ & $\begin{array}{c}-0.000096 \\
(-3.50)\end{array}$ & $\begin{array}{c}-0.024896 \\
(-1.41)\end{array}$ & 0.0033 \\
\hline Panel B: Ask & & $\beta_{0}$ & $\beta_{1}$ & $\mathrm{R}^{2}$ \\
\hline Pre-event & $\operatorname{Cov}_{a}$ & $\begin{array}{c}-0.000020 \\
(-2.01)\end{array}$ & $\begin{array}{c}-0.031281 \\
(-3.77)\end{array}$ & 0.0229 \\
\hline Event & $\operatorname{Cov}_{a}$ & $\begin{array}{c}-0.000086 \\
(-3.35)\end{array}$ & $\begin{array}{c}-0.039381 \\
(-1.53)\end{array}$ & 0.0039 \\
\hline Post-event & $\operatorname{Cov}_{a}$ & $\begin{array}{c}-0.000076 \\
(-3.85)\end{array}$ & $\begin{array}{c}-0.080244 \\
(-6.36)\end{array}$ & 0.0635 \\
\hline Panel C: Price & & $\alpha_{0}$ & $\alpha_{1}$ & $\mathrm{R}^{2}$ \\
\hline Pre-event & $\operatorname{Cov}_{p}$ & $\begin{array}{c}0.000033 \\
(1.23)\end{array}$ & $\begin{array}{c}-0.116876 \\
(-5.27)\end{array}$ & 0.0439 \\
\hline Event & $\operatorname{Cov}_{p}$ & $\begin{array}{c}0.000012 \\
(0.56)\end{array}$ & $\begin{array}{c}-0.072412 \\
(-3.46)\end{array}$ & 0.0197 \\
\hline Post-event & $\operatorname{Cov}_{p}$ & $\begin{array}{c}0.000037 \\
(2.27)\end{array}$ & $\begin{array}{c}-0.128872 \\
(-12.26)\end{array}$ & 0.2012 \\
\hline
\end{tabular}

${ }^{\mathrm{a}, \mathrm{b}}$ Statistically significance at the $1 \%$ and $5 \%$ levels, respectively. 
Table III Explanation of the bid-ask spread

The sample includes earnings announcements from firms on the Copenhagen Stock Exchange between 1989 and 1996. The pre-event window is from 45 days to 16 day before an earnings announcement. The event window is from 15 days before to 15 days after an announcement. The post-event is 16 to 45 days after earnings announcement. $C_{b} v_{b}$, Oov $_{a}$ and Cov $_{p}$ are serial covariance of daily closing bid, ask and transaction price. Price is the cross-sectional average stock price for each event window. Volume is the average trading volume in the month. Turnover is the average cross-sectional turnover ratio for each period. Market value is the average market value of the firms in the sample. t-statistics are shown in parenthe-

\begin{tabular}{|c|c|c|c|c|c|c|c|c|c|c|c|c|c|}
\hline \multirow{2}{*}{$\begin{array}{c}\text { Dependent } \\
\text { Variable }\end{array}$} & \multirow[b]{2}{*}{$X$} & \multirow[b]{2}{*}{$\alpha_{0}$} & \multicolumn{2}{|c|}{ Pre-event window } & \multirow[b]{2}{*}{$\mathrm{R}^{2}$} & \multirow[b]{2}{*}{$\alpha_{0}$} & \multicolumn{2}{|c|}{ Event window } & \multirow[b]{2}{*}{$\mathrm{R}^{2}$} & \multirow[b]{2}{*}{$\alpha_{0}$} & \multicolumn{2}{|c|}{ Post-event window } & \multirow[b]{2}{*}{$\mathrm{R}^{2}$} \\
\hline & & & $\alpha_{1}$ & $\alpha_{2}$ & & & $\alpha_{1}$ & $\alpha_{2}$ & & & $\alpha_{1}$ & $\alpha_{2}$ & \\
\hline \multirow[t]{4}{*}{$\operatorname{Cov}_{\text {price }}$} & Price & $\begin{array}{c}0.000037 \\
(1.35)\end{array}$ & $\begin{array}{c}-0.0001 \\
(-0.86)\end{array}$ & $\begin{array}{l}-0.1027 \\
(-3.71)^{b}\end{array}$ & 0.0450 & $\begin{array}{c}0.000004 \\
(0.18)\end{array}$ & $\begin{array}{l}0.0001 \\
(2.65)^{b}\end{array}$ & $\begin{array}{l}-0.1050 \\
(-4.32)^{\mathrm{b}}\end{array}$ & 0.0313 & $\begin{array}{c}0.000039 \\
(2.32)^{\mathrm{b}}\end{array}$ & $\begin{array}{c}0.0000 \\
(0.83)\end{array}$ & $\begin{array}{l}-0.1360 \\
(-10.06)^{b}\end{array}$ & 0.2021 \\
\hline & Volume & $\begin{array}{c}0.000028 \\
(0.89)\end{array}$ & $\begin{array}{c}0.0015 \\
(0.87)\end{array}$ & $\begin{array}{l}-0.1272 \\
(-5.16)^{b}\end{array}$ & 0.0502 & $\begin{array}{c}-0.000026 \\
(-1.44)\end{array}$ & $\begin{array}{c}-0.0001 \\
(-0.09)\end{array}$ & $\begin{array}{l}0.0317 \\
(1.83)^{\mathrm{a}}\end{array}$ & 0.0068 & $\begin{array}{c}0.000008 \\
(0.49)\end{array}$ & $\begin{array}{c}0.0011 \\
(1.08)\end{array}$ & $\begin{array}{l}-0.0726 \\
(-5.60)^{b}\end{array}$ & 0.0634 \\
\hline & Turnover & $\begin{array}{c}0.000026 \\
(0.82)\end{array}$ & $\begin{array}{c}0.7731 \\
(1.20)\end{array}$ & $\begin{array}{l}-0.1303 \\
(-5.26)^{b}\end{array}$ & 0.0515 & $\begin{array}{c}-0.000031 \\
(-1.74)\end{array}$ & $\begin{array}{c}0.5976 \\
(1.36)\end{array}$ & $\begin{array}{c}0.0288 \\
(1.67)\end{array}$ & 0.0104 & $\begin{array}{c}0.000010 \\
(0.57)\end{array}$ & $\begin{array}{c}-0.0802 \\
(-0.17)\end{array}$ & $\begin{array}{l}-0.0664 \\
(-5.47)^{b}\end{array}$ & 0.0613 \\
\hline & Market & $\begin{array}{c}0.000024 \\
(0.88)\end{array}$ & $\begin{array}{l}0.0000 \\
(2.27)^{b}\end{array}$ & $\begin{array}{l}-0.1311 \\
(-5.69)^{b}\end{array}$ & 0.0521 & $\begin{array}{c}0.000003 \\
(0.12)\end{array}$ & $\begin{array}{c}0.0000 \\
(1.13)\end{array}$ & $\begin{array}{l}-0.0782 \\
(-3.61)^{b}\end{array}$ & 0.0218 & $\begin{array}{c}0.000053 \\
(3.24)^{\mathrm{b}}\end{array}$ & $\begin{array}{c}0.0000 \\
(-5.15)^{b}\end{array}$ & $\begin{array}{c}-0.1206 \\
(-10.62)^{b}\end{array}$ & 0.2462 \\
\hline \multirow[t]{4}{*}{$\mathrm{Cov}_{\text {ask }}$} & Price & $\begin{array}{c}-0.000010 \\
(-0.96)\end{array}$ & $\begin{array}{l}-0.0001 \\
(-6.06)^{b}\end{array}$ & $\begin{array}{c}0.0050 \\
(0.50)\end{array}$ & 0.0792 & $\begin{array}{c}-0.000081 \\
(-3.10)^{\mathrm{b}}\end{array}$ & $\begin{array}{c}-0.0001 \\
(-1.42)\end{array}$ & $\begin{array}{c}-0.0178 \\
(-0.60)\end{array}$ & 0.0073 & $\begin{array}{c}-0.000071 \\
(-3.59)^{\mathrm{b}}\end{array}$ & $\begin{array}{l}0.0000 \\
(2.91)^{b}\end{array}$ & $\begin{array}{l}-0.1094 \\
(-6.78)^{b}\end{array}$ & 0.0765 \\
\hline & Volume & $\begin{array}{c}-0.000024 \\
(-1.99)^{\mathrm{a}}\end{array}$ & $\begin{array}{c}0.0003 \\
(0.53)\end{array}$ & $\begin{array}{l}-0.0297 \\
(-3.19)^{b}\end{array}$ & 0.0198 & $\begin{array}{c}-0.000097 \\
(-3.17)^{\mathrm{b}}\end{array}$ & $\begin{array}{c}0.0001 \\
(0.05)\end{array}$ & $\begin{array}{c}-0.0319 \\
(-1.08)\end{array}$ & 0.0024 & $\begin{array}{c}-0.000077 \\
(-3.69)^{\mathrm{b}}\end{array}$ & $\begin{array}{l}0.0038 \\
(2.97)^{\mathrm{b}}\end{array}$ & $\begin{array}{l}-0.1001 \\
(-6.10)^{b}\end{array}$ & 0.0715 \\
\hline & Turnover & $\begin{array}{c}-0.000024 \\
(-2.07)^{\mathrm{b}}\end{array}$ & $\begin{array}{c}0.2413 \\
(0.99)\end{array}$ & $\begin{array}{l}-0.0311 \\
(-3.32)^{b}\end{array}$ & 0.0213 & $\begin{array}{c}-0.000097 \\
(-3.15)^{\mathrm{b}}\end{array}$ & $\begin{array}{c}0.0136 \\
(0.02)\end{array}$ & $\begin{array}{c}-0.0320 \\
(-1.09)\end{array}$ & 0.0024 & $\begin{array}{c}-0.000076 \\
(-3.57)^{b}\end{array}$ & $\begin{array}{c}0.3462 \\
(0.59)\end{array}$ & $\begin{array}{l}-0.0828 \\
(-5.35)^{b}\end{array}$ & 0.0557 \\
\hline & Market & $\begin{array}{c}-0.000019 \\
(-1.87)^{\mathrm{a}}\end{array}$ & $\begin{array}{l}0.0000 \\
(-0.87)\end{array}$ & $\begin{array}{l}-0.0292 \\
(-3.37)^{b}\end{array}$ & 0.0241 & $\begin{array}{c}-0.000090 \\
(-3.29)^{\mathrm{b}}\end{array}$ & $\begin{array}{c}0.0000 \\
(0.33)\end{array}$ & $\begin{array}{c}-0.0412 \\
(-1.55)\end{array}$ & 0.0041 & $\begin{array}{c}-0.000068 \\
(-3.42)^{b}\end{array}$ & $\begin{array}{l}0.0000 \\
(-0.07)\end{array}$ & $\begin{array}{l}-0.0950 \\
(-6.85)^{b}\end{array}$ & 0.0814 \\
\hline \multirow[t]{4}{*}{$\operatorname{Cov}_{\text {bid }}$} & Price & $\begin{array}{c}-0.000009 \\
(-0.44)\end{array}$ & $\begin{array}{l}-0.0002 \\
(-3.81)^{b}\end{array}$ & $\begin{array}{c}-0.0125 \\
(-0.61)\end{array}$ & 0.0435 & $\begin{array}{c}-0.000061 \\
(-3.24)^{\mathrm{b}}\end{array}$ & $\begin{array}{l}-0.0001 \\
(-3.16)^{b}\end{array}$ & $\begin{array}{c}-0.0038 \\
(-0.18)\end{array}$ & 0.0236 & $\begin{array}{c}-0.000095 \\
(-3.41)^{\mathrm{b}}\end{array}$ & $\begin{array}{c}0.0000 \\
(0.65)\end{array}$ & $\begin{array}{c}-0.0339 \\
(-1.50)\end{array}$ & 0.0040 \\
\hline & Volume & $\begin{array}{c}-0.000028 \\
(-1.15)\end{array}$ & $\begin{array}{c}-0.0008 \\
(-0.62)\end{array}$ & $\begin{array}{l}-0.0580 \\
(-3.11)^{b}\end{array}$ & 0.0215 & $\begin{array}{c}-0.000073 \\
(-3.38)^{\mathrm{b}}\end{array}$ & $\begin{array}{c}-0.0012 \\
(-1.24)\end{array}$ & $\begin{array}{l}-0.0368 \\
(-1.76)^{\mathrm{a}}\end{array}$ & 0.0099 & $\begin{array}{c}-0.000065 \\
(-2.11)^{\mathrm{b}}\end{array}$ & $\begin{array}{c}0.0022 \\
(1.17)\end{array}$ & $\begin{array}{l}-0.1225 \\
(-5.02)^{b}\end{array}$ & 0.0509 \\
\hline & Turnover & $\begin{array}{c}-0.000029 \\
(-1.23)\end{array}$ & $\begin{array}{c}-0.0326 \\
(-0.07)\end{array}$ & $\begin{array}{l}-0.0599 \\
(-3.19)^{b}\end{array}$ & 0.0209 & $\begin{array}{c}-0.000077 \\
(-3.51)^{\mathrm{b}}\end{array}$ & $\begin{array}{c}-0.0148 \\
(-0.03)\end{array}$ & $\begin{array}{l}-0.0383 \\
(-1.83)^{\mathrm{a}}\end{array}$ & 0.0069 & $\begin{array}{c}-0.000056 \\
(-1.78)^{\mathrm{a}}\end{array}$ & $\begin{array}{c}-0.7606 \\
(-0.88)\end{array}$ & $\begin{array}{l}-0.1065 \\
(-4.67)^{b}\end{array}$ & 0.0499 \\
\hline & Market & $\begin{array}{c}-0.000025 \\
(-1.26)\end{array}$ & $\begin{array}{c}0.0000 \\
(0.95)\end{array}$ & $\begin{array}{l}-0.0627 \\
(-3.66)^{b}\end{array}$ & 0.0219 & $\begin{array}{c}-0.000066 \\
(-3.31)^{\mathrm{b}}\end{array}$ & $\begin{array}{l}0.0000 \\
(-0.35)\end{array}$ & $\begin{array}{l}-0.0372 \\
(-1.92)^{\mathrm{a}}\end{array}$ & 0.0074 & $\begin{array}{c}-0.000112 \\
(-4.12)^{\mathrm{b}}\end{array}$ & $\begin{array}{c}0.00091 \\
(5.78)^{\mathrm{b}}\end{array}$ & $\begin{array}{l}-0.0647 \\
(-3.40)^{b}\end{array}$ & 0.0577 \\
\hline
\end{tabular}

${ }^{\mathrm{a}, \mathrm{b}}$ Statistically significant at 5 and 1 percent levels, respectively. 


\section{Table IV Components in the Bid-Ask Spread}

Components of the bid-ask spread are estimate for the pre-event, event, and post event window. Stoll's (1989) methodology is used to estimate the spread. The pre-event window is from 45 days to 15 day before an earnings announcement. The event window is from 15 days before to 15 days after an announcement. The post-event is 15 to 45 days after earnings announcement. The sample includes a total of 690 announcements from firms on the Copenhagen Stock Exchange from 1989 to 1996. The cost per dollar of price estimates are obtained by multiplying proportional spread with the mean percentage spread, similar to the methodology by Affleck-Graves, Hedge, and Miller (1994). The p-values in parentheses are obtained using a bootstrap simulation involving 10,000 replications.

\section{Estimated Components}

Pre-event Event
Post-event

Type:

Panel A: Proportion of Percentage Spread

\section{Difference}

$\begin{array}{lll}\text { Event - } & \text { Post - } & \text { Post } \\ \text { Pre } & \text { Event } & \text { Pre }\end{array}$

\begin{tabular}{lcccccc}
\hline Adverse selection cost & 0.5534 & 0.7170 & 0.5110 & 0.1636 & -0.2060 & -0.0424 \\
& & & & $(0.406)$ & $(0.295)$ & $(0.829)$ \\
Inventory holding cost & \multirow{2}{*}{0.2673} & \multirow{2}{*}{0.1897} & 0.3126 & -0.0775 & 0.1228 & 0.0453 \\
& & & & $(0.301)$ & $(0.204)$ & $(0.380)$ \\
Order processing cost & \multirow{2}{*}{0.1793} & \multirow{2}{*}{0.0933} & \multirow{2}{*}{0.1765} & -0.0861 & 0.0832 & -0.0029 \\
& & & & $(0.253)$ & $(0.259)$ & $(0.491)$ \\
\hline
\end{tabular}

Panel B: Cost per Dollar of Price

\begin{tabular}{lcccccc}
\hline Adverse selection cost & 0.9521 & \multirow{2}{*}{1.2311} & 1.1123 & 0.2789 & -0.1188 & 0.1602 \\
& & & & $(0.156)$ & $(0.546)$ & $(0.416)$ \\
Inventory holding cost & \multirow{2}{*}{0.4598} & \multirow{2}{*}{0.3258} & 0.6804 & -0.1340 & 0.3547 & 0.2206 \\
& & & & $(0.183)$ & $(0.008)^{\mathrm{c}}$ & $(0.068)^{\mathrm{a}}$ \\
Order processing cost & \multirow{2}{*}{0.3085} & \multirow{2}{*}{0.1601} & \multirow{2}{*}{0.3841} & -0.1484 & 0.2240 & 0.0756 \\
& & & & $(0.125)$ & $(0.041)^{\mathrm{b}}$ & $(0.279)$ \\
\hline
\end{tabular}

$\overline{\mathrm{a}, \mathrm{b}, \mathrm{c}}$ Statistically significance at the 10,5 , and 1 percent levels, respectively. 


\section{Table V Component of the Bid-Ask Spread for Positive and Negative News}

Components of the bid-ask spread are estimate for the pre-event, event, and post event window. Stoll's (1989) methodology is used to estimate the spread. The pre-event window is from 45 days to 15 day before an earnings announcement. The event window is from 15 days before to 15 days after an announcement. The post-event is 15 to 45 days after earnings announcement. The sample includes a total of 690 announcements from firms on the Copenhagen Stock Exchange from 1989 to 1996. The cost per dollar of price estimates are obtained by multiplying proportional spread with the mean percentage spread, similar to the methodology by Affleck-Graves, Hedge, and Miller (1994). The p-values in parentheses are obtained using a bootstrap simulation involving 10,000 replications.

\section{Positive earnings surprises}

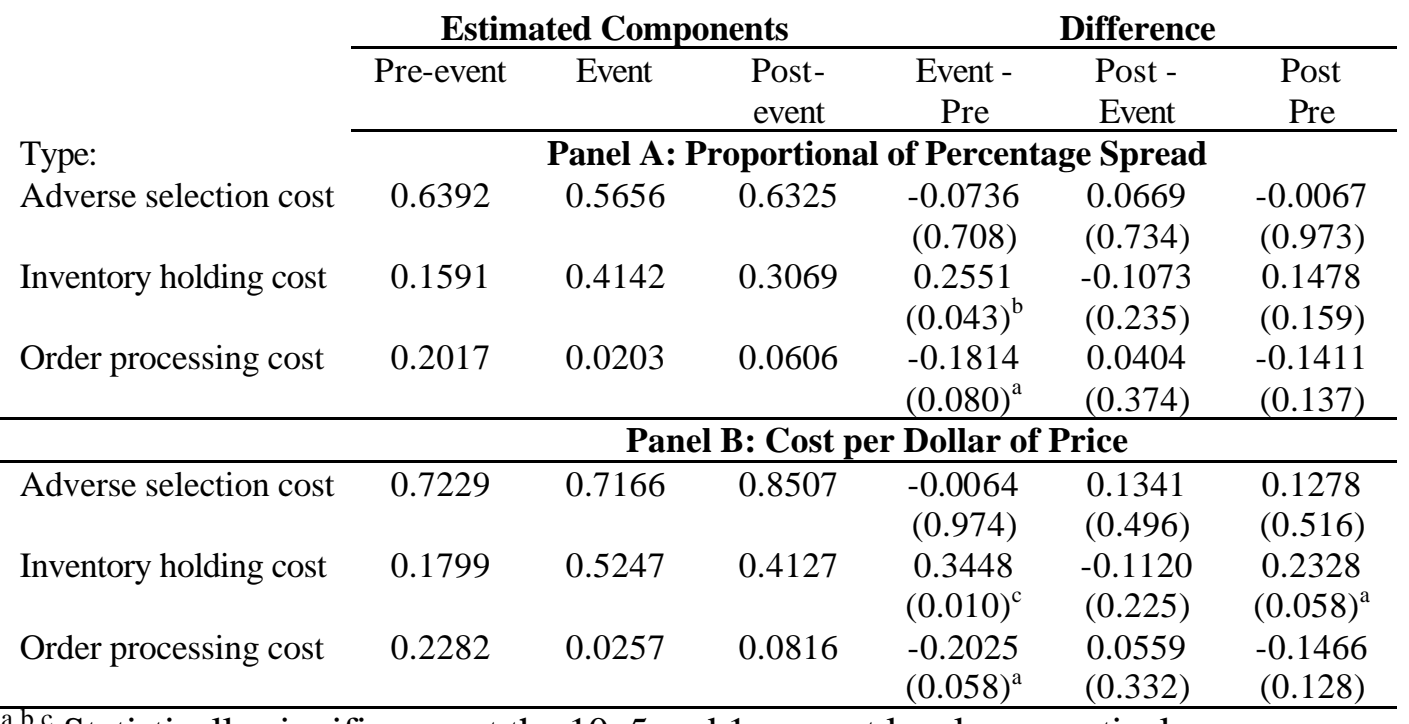

$\overline{a, b, c}$ Statistically significance at the 10,5 and 1 percent levels, respectively.

\section{Negative earnings surprises}

\begin{tabular}{cccccc}
\multicolumn{2}{c}{ Estimated Components } & \multicolumn{3}{c}{ Difference } \\
\hline $\begin{array}{c}\text { Pre- } \\
\text { event }\end{array}$ & Event & $\begin{array}{c}\text { Post- } \\
\text { event }\end{array}$ & $\begin{array}{c}\text { Event - } \\
\text { Pre }\end{array}$ & $\begin{array}{c}\text { Post - } \\
\text { Event }\end{array}$ & $\begin{array}{c}\text { Post } \\
\text { Pre }\end{array}$ \\
\hline \multicolumn{4}{c}{ Panel C: Proportional of Percentage Spread } \\
0.3046 & 0.6286 & 0.6994 & 0.3239 & 0.0709 & 0.3948 \\
& & & $(0.099)^{\mathrm{a}}$ & $(0.719)$ & $(0.045)^{\mathrm{b}}$ \\
0.2849 & 0.0829 & 0.2613 & -0.2020 & 0.1784 & -0.0236 \\
& & & $(0.087)^{\mathrm{a}}$ & $(0.115)$ & $(0.0437)$ \\
0.4105 & 0.2886 & 0.0393 & -0.1219 & -0.2493 & -0.3712 \\
& & & $(0.173)$ & $(0.027)^{\mathrm{b}}$ & $(0.002)^{\mathrm{c}}$ \\
\hline
\end{tabular}

\begin{tabular}{cccccc}
\multicolumn{7}{c}{ Panel D: Cost per Dollar of Price } \\
\hline 0.4963 & 0.9963 & 1.0443 & 0.5000 & 0.0480 & 0.5480 \\
& & & $(0.011)^{\mathrm{b}}$ & $(0.801)$ & $(0.005)^{\mathrm{c}}$ \\
0.4641 & 0.1313 & 0.3901 & -0.3328 & 0.2587 & -0.0740 \\
& & & $(0.013)^{\mathrm{b}}$ & $(0.041)^{\mathrm{b}}$ & $(0.309)$ \\
0.6686 & \multirow{2}{*}{0.4574} & 0.0586 & -0.2113 & -0.3987 & -0.6100 \\
& & & $(0.051)^{\mathrm{a}}$ & $(0.001)^{\mathrm{c}}$ & $(0.000)^{\mathrm{c}}$ \\
\hline
\end{tabular}

